\title{
Towards enhancing national security in Nigeria: The roles of library
}

\author{
Lazarus C. Njoku \\ Department of Library and Information Science \\ Faculty of Education \\ Imo State University, Owerri. \\ E-mail: lazarus_njoku@yahoo.com \\ Cell: +2348032099334 \\ Eucharia Ken-Agbiriogu \\ Department of Library and Information Science \\ Faculty of Education \\ Imo State University, Owerri. \\ Email: ukay98@gmail.com \\ Cell: +2348033126169
}

\begin{abstract}
The study investigated the role of the library on national security in Nigeria. It was carried out to identify the extent the library can contribute to national security effectiveness through information sharing, information provision, and public education. This is because if the problem of insecurity must reduce in our society, all the stakeholders, including the library has positive roles to play. The study highlighted the strategies adopted by the library in promoting national security. They include: Moral boosting strategy, selective dissemination of peace information/ education strategy, transformation and change strategy, peace and reconciliation strategy, social integration strategy, national development strategy, and free access to information resources strategy. Based on the these, it was recommended that security agencies should be as a matter of deliberate government policy, work closely with the library in the war against insecurity; library should design a blueprint for security consciousness; and rural libraries/mobile libraries should be more functional to distribute literacy materials to help rural dwellers be better information sensitive in this information driven society.
\end{abstract}

Keywords: National security, Roles of libraries

\section{Introduction}

It is not a gainsaying the fact that any country that wants to achieve growth and sustainable development must always maintain national security in its system. National security is the preservation of the values a nation holds as relates to the defence of its territory from human as well as nonhuman threats and guides in the pursuit of national interest in the international system (Ubah, 2015). This means that national security is the process of providing protection for the people of a country, properties and adherence to the principle of the rule of laws and human rights by the government. In this direction, it should be noted that all effort put in place by the government to guarantee nation security in our society is not rock- solid and effective if the library is not at fore-vanguard of the fight. This means that the role of the library is imperatively a desideratum in combating insecurity, social unrest in the society especially Nigeria.

Traditionally, library is collection of books, manuscripts, journals, and other sources of recorded information. In the last 50 years, libraries have increasingly developed into a provider of information resources and services that do not even require a building (Ogunsola, 2011). The primary role of the library is to acquire, process, preserve, and disseminate recorded information. It is therefore the responsibility of the library to enlighten the youths and other members of the 
Lazarus C. Njoku and Eucharia Ken-Agbiriogu: Towards enhancing national security in Nigeria: the roles of library

community it serves by presenting them with factual information that will guide their actions and help make good conclusions that will promote peace (Ugulu \& Oghuvwu, 2015). Since knowledge and information are so vital for all round human development, library and other institutions that handle and manage knowledge and information are indeed invaluable in national security.

The roles of libraries in this information driven society are underestimated especially in the area of security maintenance and sustainability. According to John (2018), of all the roles that librarians and library play, two are critical to modern society as we know it. The first is the access role of the library as the place where the information seeker can access information without restriction. The second focused on user education. The access (the first role) has been the worldwide function of the library to acquire, organize, provide on-going access to variety of information as well as preserving the valued cultural heritage for long term access; library by its vintage position promote learning and long life education to the generality of the public. The focused of the second role (user education) takes place even beyond the library as it serve as an avenue to educate people on how to source and get information on any issues, like security. Library organizes social-cultural events and enlightment programmes to the general public, this includes: awareness creation on current ravaging pandemic, sensitization on news electoral system, enlightment on boarded security issues, cultural festival etc. (Akanwa \& UdoAnyanwu 2017). Through these inherent responsibilities, education and social events are enhanced for development and growth in the society. These two fundamental roles have differentiated the library from all other institutions in our contemporary society." This is where the civic and social responsibility of the library takes centre stage. Social responsibility is a part of librarianship (Kagan, 2015).

According to Ossai-Ugbah (2013), the issue of national security is therefore core value of librarianship. Since no meaningful learning, education and development can take place in a context of insecurity and brazen destruction of lives and property, the onus lies on the library for quality services delivery through provision of information materials and dissemination of information that can contribute to peace and national security in Nigeria. The library as a storehouse of information has positively broadened its scope of societal relevance across time to become not only a collection books, book related and non-book materials but also a gateway through which information can be conveyed to people irrespective of location. Omotayo (2015) observed that in war situations in a literate society, use of libraries increases as users flock to libraries to find information to guide them. Information that can promote peace, unity, progress, peaceful co-existence, and harmonious relationship among all the communities must therefore be available in libraries.

Librarians, therefore, in promoting access to this information, act as agents of the promotion of communal peace and reconciliation (Ugulu \& Oghuvwu, 2015). Boko Haram, Militia from the oil rich Niger Delta, ritual killings and kidnapping could be reduced through the use of the library to educate the people on the need to build a peaceful society. This is because, mostly all the conflicts in our society today are caused by lack of information and right knowledge to live in civil society. Information is a vital tool to the development of every individual or nation. Information is of paramount importance as it relates to the environment which in turn affects the totality of human's life. The 
Lazarus C. Njoku and Eucharia Ken-Agbiriogu: Towards enhancing national security in Nigeria: the roles of library

library serve the most appropriate channel in disseminating information across to people of all work of life.

In view of Ogunsola, (2011), the library importance is clearly reflected in the six major roles with. These roles include: custodial of knowledge for present and future heritage, educational role like long life education, adults education, building of mind; research information; informational; cultural and recreational. Today modern libraries with the aid of modern technologies perform these roles in an enhanced ways.Libraries serve as the most veritable medium or channel for provision of rightful and timely information to the people especially those living the rural areas (Ugulu and Ughavwu, 2015)

The library promotes the culture of peace. In the society. In Nigeria today, social unrest has become the order of the day, the youths have become agents of conflictin the hands of our narrow minded leaders. The youths are venerable to the instigation and manipulation of violence by our leaders in the pursuit of their parochial interests. This is so because they have not been given any good training in peace education coupled with the hopelessness of the situation of millions of unemployment and idleness in the society. Meanwhile, library can be used as instrument for conflict resolution. Library serve as a means for providing the required information and enlighten the communities to reduce the tension and uncertainty that translate to crises (Ugulu and Oghuvwu, 2015).

This will go a long way in training or educating youths and social leaders on their role in promoting the culture of peace, and then enjoin citizens to naturally prefer pacific methods of settling disputes to violence or fighting (Oghuvwu, 2007). The society should encourage the development of knowledge house (libraries and information centres), encourage the use of libraries in society to reduce the rate of literacy and deviance in the society and inform the youths on the significance of education in human life and activities which can be achieved through library peace education programme. The work is divided into three major sections. The first section covers the introduction, which serves as overview of the work. The second section focuses on the major conceptual issues and the objectives of the study. it covers the concept of library, the concept of security and national security, contributions of the library to national security and the strategies adopted by the library in promoting national security. The third section is conclusion.

\section{The concept of library}

Library has many definitions. Library is an important intellectual resource of the nation at large, as it helps to promote information sharing, studies and research. Ezennia (2012) defined the library as "an institution for care of collection of books that make them accessible to prospective users". He went further to say that stocks in the library are audio visual materials (magnetic tapes, phone records, films) arranged in a systematic manner to allow for easy access and location of individual items for loan, reference or research. Dominant among the recorded information materials are books and other printed materials, thus the library contains information materials some of which are in book form and others in non-book form. The non-book library materials are referred to as audio-visual media resources. In the same view, Eziekoli (2012) agreed that non-book materials include the radio, the television, film strips, slides, tapes, video cassettes, records, computers, maps and globes.

Library serves as the citadel of information generation and dissemination. Ude (2008), in his own opinion states that libraries provide the instructional materials 
Lazarus C. Njoku and Eucharia Ken-Agbiriogu: Towards enhancing national security in Nigeria: the roles of library

to enrich the users, supplement the textbook, give users unlimited opportunity to learn and keep users, teachers and students up to date on new social, economic and scientific development, provide an opportunity for users to solve the problems of their information needs in cultural, political, developmental, educational, and socio-economic issues. According to Ibrahim and Ibrahim (2013), traditionally, a library has been defined as a place, a room or a building where books, journals and other sourced of information are kept and used for study, research and recreation. The library is a very important institution in the society. Its overall importance and never be over emphasized.

\section{The concept of security and national security}

Security is a state of being safe and the absence of fear, anxiety, danger, poverty and oppression. It is the preservation of core values and the absence of threats to these values (Alli, 2010:73). Imobighe (2010:224) opines that security is the freedom from threats to a nation's capability to defend and develop itself, promote its values and lawful interest. For Zabadi (2005:3), security is a state in which people or things are not exposed to danger of physical or moral aggression, accident, theft or decline. This view is associated with the survival of the state and the preservation of its citizens.

To Ugulu and Oghuvwu, (2015), National security can be defined as the actions and policies taken by a nation against all internal and external threats to its borders, economy, and stability. It doesn't have to be terrorism or an enemy nation, though it often is. The security interest includes safety of life and property, economic, physiological, mental well-being and the freedom to pursue the attainment of legitimate objectives without hindrance. This definition is holistic and most relevant to us as it sees the objective of national security as elimination of all distractions in order to bring about growth and development of the society and its constituents. In other words, every national security structure must be seen in the light of its two core obligations of preserving the safety of its citizens at home and abroad, and preserving the integrity of the borders and assets of the country.

Besides, Held (2018:226) gives a traditional meaning of national security. $\mathrm{He}$ describes national security as "the acquisition, deployment and use of military force to achieve national goals". Romm (2013) describes it as the lack of danger or risk to hold standards, values and ideals and the absence of fear that such values will be attacked now or in the future. Thus, national security is the preservation of the values a nation holds as relates to the defense of it territory from human as well as nonhuman threats and guides in the pursuit of it national interest in the international system. However, national security loosely defined refers to the protection of the interests of a country. This is where it takes a wide meaning as all embracing dimension of national life (Hussain, 2008 and Iradia, 2011) because threat posed to any element of national power creates security problems.

\section{The contributions of the library to national security}

Libraries have always been a key contributor to national development and it is appropriate that they take a leadership role in the current movement on national security (Ossai-Ugbah, 2013). The word 'national security' is used by politicians and military leaders in the line of a policy objective. The role of the library in national security is not just to spread information in a particular area but to offer a holistic approach, around all aspects of the policies of the country called Nigeria. Here, the contributions of the library to 
Lazarus C. Njoku and Eucharia Ken-Agbiriogu: Towards enhancing national security in Nigeria: the roles of library

national security could be summarised thus:

\section{Effective information} dissemination on security issue: Currently, the war on terror and terrorism is not only fought by the armed forces but by everybody as an agent of policing. As the whole nation is engaged in the economic, scientific, political and social crusade against insecurity and social unrest, for the library, information is veritable tool to address the situation. Library is the centre for peace and conflict resolution which is achievable through the information dissemination and enlightment mechanism (Hali, 2013). "National security is the requirement to maintain the survival of the state through the use of economic, diplomacy, power projection and political power". Information is therefore a crucial factor in national security. This is because the line between security and insecurity lie in information given or information withheld. The ability to use information and its associated tools is a source of power for any nation which the library and librarians are best equipped to do. In Nigeria's current security challenge, citizens and government must recognize this need for information use and literacy as a means of ensuring peace and engendering national security (Noruzi, 2016). Information remains the only product which the library handles and this includes all media in which the information is shaped. The only means through which the real integration of people living in political, economic, religious and ideological poles could be brought together is through the actual cooperation and exchange of vital information between the two: the terrorist and the terrorized (OssaiUgbah, 2013). The philosophy behind the library and its services is based on information generation, categorization, conservation, and management. At this time, when Nigeria is still in democratic embryo, ideological divides which is the threshold upon which terrorism thrives can be countered through effective information dissemination. There is an urgent need for provision of "right information, in the right format, for the right people, at the right time, and in the right place" to stem the tide of ignoramus decadence. The long years of political and religious distrust in the country has fanned the flames for crises that have polarized the society and divided Nigerians across ethno-religious lines. To allow every Nigerian to read from the same page, it is important to flash the searchlight of information dissemination on restive areas so that they cannot be used to destroy the hard earned peace and unity the country is presently enjoying.

2. Work outside the library walls: Ogunsola (2011) observed that librarianship has undergone a radical change in recent years, which will be continued in the future. As libraries have changed, so too, has the role of the librarian. The work of librarians has moved outside library walls. Librarians have begun to work in the information industry as salespeople, designers of new information systems, researchers, and information analysts. They are 
Lazarus C. Njoku and Eucharia Ken-Agbiriogu: Towards enhancing national security in Nigeria: the roles of library

also found in such fields as marketing and public relations and in such organizations as law firms, where staffs need rapid access to security information. Security information in every facet of human endeviour has become an inevitable imperative. Librarians generate security information and make it available to members of their organizations and public for building both individual and collective alertness as well as neighbourhood co-operation (Ughegbu, 2001).

\section{Mobile library and} enlightenment programmes: Though information officers and librarians may not be in battle field or war front, they are fighting behind the scene in providing technical information services to experts in military and in other fields using the language they understand most since language is a synergy. In providing information services, librarians may need to adopt mobile library strategy as well as enlightenment programmes to bring library services to the doorsteps of citizens and educate them on issues that borders on national security. Nwalo (2013) observed that the compilations made by mobile libraries reflect perceived needs of local communities. This will help to provide security services to communities and help citizens and patrons of the library attain maximum information services, in spite of their vocations. Ifidon and Ahiauzu (2016) defined information as "structured data that causes a human mind to change its opinion about the current state of real world and contribute to a reduction in the uncertainty of the state of the system". Since information is a transformation agent, a shaper of perspectives and philosophies of life, the onus lies on libraries as information centers and librarians as information managers to ensure that Nigerians have access to information that will direct their actions.

4. Give accurate, timely, and comprehensive security information: Information therefore is a sine qua non for individual and collective freedom and attainment of national security. Anasi (2010) citing Sokari (2016) agrees that "information is necessary for people to be liberated from the shackles of ignorance, misconceptions, economic stagnation, social unrest, and political instability. Social cohesion cannot be achieved without timely, accurate, and relevant information." This is because information is fresh ideas or fact taken out of a person's surrounding for use with the objective of transforming behaviour in all areas of human life (Ajegbomogun, 2008). Information helps create enlightened and responsible citizens. The library is the gateway to information. It is a place where information is acquired, processed, repackaged, preserved, and disseminated (Anasi, 2010).

5. Use of electronic media to promote and expand security awareness: A nation not mobilized enough to withstand terrorism cannot aspire to preserve its freedom, faith and ideology for long. To mobilize people, the use 
Lazarus C. Njoku and Eucharia Ken-Agbiriogu: Towards enhancing national security in Nigeria: the roles of library

of electronic media comes to mind. Currently, electronic media is one of the most effective and powerful means of mass mobilization. Therefore, it is in this regard that libraries and librarians can ginger up the electronic media to promote and expand security awareness among the people at large. The library through the media has been waging war of its own to counter the hostile propaganda from insurgents and terrorists in Nigeria. The government through the library (using electronic media) can fund effective counter propaganda campaigns that will sensitize the citizens to the ills of terrorism and win over their sympathizers.

\section{Strategies adopted by the library in promoting national security}

There are many strategies which library and librarians adopt in promoting national security. They are discussed thus:

1. Moral boosting strategy: The librarian, being a mass mobilize knows how to use effective electronic media to promote and expand security awareness among the people at large. One of the most effective tools to maintain national security is through propaganda and the primary tool of propaganda is the media; hence libraries use the media to wage war of its own to counter the hostile propaganda campaign of the insurgents [for example boko haram, headsmen problem, and Movement for the Emancipation of the Niger Delta (MEND)], and win over their sympathizers as they become sensitized and informed (Nwalo, 2013). Some of the counterpropaganda techniques that librarians could use include repeating the lies of the terrorists, attacking personal opinions disguised as facts, headlining propaganda, selective control of information and the yellow journalism "in the military parlance, morale is the will to fight for the national cause to the last".

2. Selective dissemination of peace information/ education strategy: The philosophy behind the library and its services is based on information collection, categorization, conservation and management. At this time, when Nigeria is still in democratic embryo, ideological divides which is the threshold upon which terrorism thrives can be countered effective information dissemination. There is an urgent need for provision of "right information, in the right format, for the right people, at the right time and in the right place" to stem the tide of ignoramus decadence (Ubah, 2015). The long years of political and religious destruct as the country fanned the flames for crisis that have polarized the society and divided Nigerians across ethno-religious lines. To allow every Nigerian read from the same page, it is important to flash the search light of information dissemination on restive areas so that they cannot be used to destroy the hard earned peace and unity the country is presently enjoying. This is so because the more informed the citizen are, the less aggressive and arrogant they will be. Thus radicalization is prevented.

3. Peace and reconciliation strategy: Library is a judgment free zone in which a citizen can investigate interests of terrorists with aggrieved communities 
Lazarus C. Njoku and Eucharia Ken-Agbiriogu: Towards enhancing national security in Nigeria: the roles of library

without worry of embarrassment or exposure. A greater understanding of the differences and similarities between people of the world can potentially initiate and expands feelings of tolerance and empathy for cultures, religions and traditions outside of one's immediate sphere (Zabadi, 2015). Hence, in conflicting situations, the library provides information resources and guidance that can promote peace, unity, progress, peaceful coexistence and harmonious relationship among agitating communities. Example when South African Youths confirmed from their libraries of Nigerian government fought apartheid and international consequences of xenophobia attacks, their leaders called Nigerian government for reconciliation.

4. Social integration strategy: Library is one of the major places in the world through which the real integration of people with diverse political, economic, religious and ideological spheres could be brought together through actual cooperation and exchange of vital information (Becker, 2013). It is a judgment free zone that allows the exchange of vital information between the terrorist and terrorized; the able and disabled; the rule and the people; the lord and the slaves; the complainant and the plaintiff; the strong and the weak; the acquitted and the criminal; the secured and the insecure etc.

5. National development strategy: National security loosely defined refers to the protection of the interests of a country like Nigeria. Threat posed to any element of national power creates security problems hence the word "national security" is used by politicians and military leaders in policy making objectives (Ifidon and Ahiazu, 2015). Hence, the role of library in national security is to offer a holistic information dissemination approach around all aspects of the policies of the country called Nigeria so that the war on terror and insecurity is not only fought by the armed forces but by the whole citizenry in their different facet of human endeavours. Librarians contribute to policy directives of national development of Nigeria by very of providing technical services to experts in order fields using the language they understand most since language is synergy. Also, librarians have begun to work in information industry as salespersons, designers of new information, researchers, information analyst, marketing, public relations where staff need access to rapid informationfor effective operation of the organization.

\section{Conclusion}

The issue of national security is therefore core value of librarianship. Since no meaningful learning, education and development can take place in a context of insecurity and brazen destruction of lives and property, the onus lies on the library for effective services. It is obliged to disseminate information that can contribute to peace and national security in Nigeria as well as helping the citizens to understand their roles in national security (Noruzi, 2016). The library as a storehouse of information has positively broadenits scope of responsibility by being not only a place that houses information resources but a gateway through which information can be conveyed to people irrespective of location. Libraries and librarians should be 
Lazarus C. Njoku and Eucharia Ken-Agbiriogu: Towards enhancing national security in Nigeria: the roles of library

seen as important tools in national security. National security is possible through the utilization and collaboration of library, human, and material resources. Libraries play crucial roles in inculcating positive values, attitudes, and behaviours that promote harmonious relationships.

The paper recommends that the:

1. Security agencies should be as a matter of deliberate government policy work closely with libraries in the war against terror.

2. Libraries should design a blueprint for security consciousness.

3. Rural libraries/mobile libraries should be more functional to distribute literacy materials to help rural dwellers be better information managers.

4. Special libraries, like military libraries and policing based libraries should be revitalized to support the works security agencies by way of providing and managing the information system.

5. Police community relation information centres could be strengthened through revival of the rural libraries to educate the rural dwellers on the need to maintain peace and harmony in the society. If all these measures suggested above are taken and implemented our stakeholder, the security challenges in our society, especially Nigeria would be a thing of the past.

\section{References}

Ajegbomogun, F.O (2008).Information availability and the extent of use in public library Abeokuta.Borno Library, Archival, and Information Science Journal 7 (1), 65-74.

Akanwu, P.C and Udo-Anyanwu, J. (2017).Information resources in libraries.Owerri: Supreme Publicities
Alli, W.O (2010). The changing environment of Nigeria's foreign policy. In Osita, C.E (ed). Beyond 50 years of Nigeria's foreign policy: Issues, challenges and prospects( $\mathrm{p} 2)$. Lagos: Nigerian Institute of International Affairs.

Anasi, S.N.I (2010).Curbing youth restiveness in Nigeria: The role of information and libraries. Library Philosophy and Practice. Retrieved from http://unllib.unl.edu/LPP/lpp20 10.htm.

Becker, P.C (2013).In time of war: When the nation is in crisis, America's libraries respond. American Libraries. 34(5), 54-57.

Ezennia, S. (2012). The role of school librarie. Technical Education Today, 3(1), 1-2

Eziekoli, S.O (2012). Non-book materials in education.Proceeding of the first Northern State book fair, Kaduna Library Board, Kaduna State.

Gamble, M.W \&Kwerliambli, T. (2018). Introducing mass communications. Singapore: Mc-Graw Hill.

Hali, S.M (2013).Media imperialism.The Defence Journal. 2 (3), 7-9

Hussain,.N (2008).The role of media in national security: A case study of 1998 nuclear explosions by Pakistan. South Asian Strategic Stability Institute (SASSI).

Ibrahim, I. \& Ibrahim U.A (2013).National Open University Plan: Enhancing higher. TechnicalEducation, 6(1), 2

Ifidon, S.E. \& Ahiauzu, B. (2015).Information and conflict prevention in the Niger Delta Region of Nigeria.African Journal of Libraries, Archives, and Information Science. 15 (2), 125-132.

Imobighe T.A (2010).Doctrine for and threats to internal security. In A.E Ekoko and M. A Vogt (Eds) Nigerian Defence Policy: Issues and Problems. Lagos: Malt house Press. 
Lazarus C. Njoku and Eucharia Ken-Agbiriogu: Towards enhancing national security in Nigeria: the roles of library

Iredia, T. (2011). "What is national security"?

http://www.vanguardngr.com /2011/12/what-is-national-security/

John, N. (2018). Libraries and the global information

infrastructure.www.unesco.org/web world/infoethics2/eng/papers/paper_ 13.rtf.

Kagan, A.I (2015). IFLA and social responsibility: A core value of librarianship.InSeidelin and Stuart Hamilton(Ed).Libraries, national security, freedom of information laws and social responsibilities IFLA/FAIFE World Report. (3343).Susanne Copenhagen: IFLA/FAIFE.

Noruzi, A. (2016). Where is the station of knowledge (libraries) in scientific and economic development? Available:

http://nouruzi.persianblog.ir/post/2 33.

Nwalo, K. I.(2013). Fundamentals of library practice: A manual on library reentries. Ibadan: SterlingHoden Publishers Ltd.

Oghuvwu, V. (2007). The role of library in nation building: The Nigeria prospective. Nigerian Journal of Research and Production,11(3).

Ogunsola, L.A (2011). The next step in librarianship: Is the traditional library dead?Library Philosophy and

Practice.http://unllib.unl.edu/LPP/O lili.

Omotayo, B.O (2015).Women and conflict in the new information age: Virtual libraries to the rescue. A paper presented at the world Library and Information Congress: 71st IFLA General Conference and Council August $14^{\text {th }}, 2005$, Oslo, Norway.

Ossai-Ugbah, N.B (2013). The role of library and librarians in promoting national security in
Nigeria.Academic Journal of Interdisciplinary Studies, 2(2), 99 104.

Sheriff, F.F \&Oviasogie F.O (2015). Insurgency and national security challenges in Nigeria: Looking back, looking ahead.Ibadan: Sterling-Hoden Publishers Ltd.

Sokari, U. (2016). The role of library and information management in the promotion of information literacy in the $21^{\text {st }}$ century in Nigeria.International Journal of Research in Education, 3(2)Ibadan: Sterling-Hoden Publishers Ltd176 $-181$.

Ubah, C.N (2015). Impact of information communication technology in university administration in Imo State University (1999-2014).A Seminar Paper, Presented to the Department of Political Science, Abia State University, Uturu. August 2015.

Ude, N. (2008). Projecting a positive image of public libraries in Nigeria through public relations.African Journal of Libraries, Archives and Information Science, 16 (2), 129135.

Ugulu, O.L \&Oghuvwu, V. (2015).The impact of the library and information in promoting national security in Nigeria.International Journal of Librarianship and Administration, 6(1), 61-76.

Uhegbu, A.N (2001).The information user: issues and themes. Okigwe, Imo State: Justman Publishers Intl.

Zabadi, A.S (2015). Terrorism in asymmetrical conflict: Ideological and structural aspects. New York, NY: Oxford University Press.
About the authors
Lazarus C. Njoku is a lecturer in the Department of Library and Information
Science, Faculty of Education, Imo State 
Lazarus C. Njoku and Eucharia Ken-Agbiriogu: Towards enhancing national security in Nigeria: the roles of library

University, Owerri. He has numerous

published research works to his credit.

Eucharia Ken-Agbiriogu is a banker and a

Ph.D student in the Department of Library

and Information Science, Faculty of

Education, Imo State University, Owerri,

Nigeria

Library and Information Perspectives and Research, Volume 2 Number 1, 2020 